\title{
JPEB
}

Jurnal Penelitian Ekonomi dan Bisnis, 5 (1), 2020, Hal: 1 - 15

http://www.jpeb.dinus.ac.id

\section{TINGKAT KEPATUHAN WP BADAN DALAM MEMENUHI KEWAJIBAN PERPAJAKANNYA MELALUI PEMERIKSA PAJAK, KESADARAN DAN KUALITAS PELAYANAN PADA KPP PRATAMA SEMARANG BARAT}

\author{
Belia Natasya Putri ${ }^{1}$ dan Ira Septriana ${ }^{2 *}$ \\ ${ }^{1,2}$ Program Studi Akuntansi, Fakultas Ekonomi dan Bisnis, Universitas Dian Nuswantoro \\ Jalan Nakula I No. 5-11 Semarang, Indonesia \\ *Corresponding Author : ira.septriana@dsn.dinus.ac.id
}

Diterima: November 2019; Direvisi: Januari 2020; Dipublikasikan: Maret 2020

\begin{abstract}
The purpose of this study is to determine the level of compliance of the Corporate Taxpayer in meeting tax obligations by increasing tax auditors, awareness and service quality at the West Semarang Pratama Tax Office. This study uses the population of Corporate Taxpayers registered at the West Semarang Pratama Tax Office with a population in 2018 of 11,723 Corporate Taxpayers. The number of samples used was 100 Corporate Taxpayers from the West Semarang Pratama Tax Office. In this study, the authors used multiple analysis tools to analyze the research data. This study has the result that there is a significant influence between tax auditors with taxpayer compliance, which means that more tax auditors can make taxpayers have increased awareness. The second hypothesis is that there is a significant positive effect between tax awareness and tax compliance. This means that the higher the level of tax awareness, the higher the taxpayer compliance. The last hypothesis has the result that there is a significant positive effect between service quality with taxpayer compliance. These results can be interpreted that if the quality of service for taxpayers has increased the taxpayers will be more obedient.
\end{abstract}

Keywords : Tax Audit; Awareness; Service Quality; Tax Compliance

\section{ABSTRAK}

Tujuan dari penelitian ini adalah untuk menentukan tingkat kepatuhan WP Badan dalam memenuhi kewajiban pajak dengan meningkatkan pemeriksa pajak, kesadaran dan kualitas layanan di KPP Pratama Semarang Barat. Penelitian ini menggunakan populasi pada WP Badan yang terdaftar di KPP Pratama Semarang Barat dengan jumlah populasi pada tahun 2018 sejumlah 11.723 WP Badan. Jumlah sampel yang digunakan adalah 100 WP Badan dari KPP Pratama Semarang Barat. Dalam penelitian ini penulis menggunakan alat analisis berganda guna menganalisis data hasil penelitian. Penelitian ini mempunyai hasil yaitu bahwa ada pengaruh yang signifikan antara pemeriksa pajak dengan kepatuhan wajib pajak, yang mempunyai arti bahwa lebih banyak pemeriksa pajak yang dapat membuat para wajib pajak itu mempunyai kesadaran yang meningkat. Hasil hipotesis yang kedua yaitu ada pengaruh positif signifikan antara kesadaran pajak dengan kepatuhan wajib pajak. Hal tersebut mempunyai arti bahwa semakin tinggi tingkat kesadaran pajak, maka semakin tinggi kepatuhan wajib pajak. Hipotesis yang terakhir mempunyai hasil yaitu ada pengaruh positif yang signifikan antara kualitas layanan dengan kepatuhan wajib pajak. Hasil tersebut dapat diartikan bahwa jika kualitas layanan terhadap wajib pajak mengalami peningkatan maka wajib pajak akan semakin patuh.

Kata Kunci: Pemeriksa Pajak; Kesadaran; Kualitas Layanan; Kepatuhan Pajak

DOI: $10.33633 /$ jpeb.v5i1.3229 


\section{PENDAHULUAN}

Pemerintah dalam mengelola negaranya membutuhkan suatu pemasukan agar negara tersebut dapat mengalami kemajuan ataupun negara tersebur dapat membuat masyarakatnya mempunyai kehidupan yang layak dan kesejahteraannya terjamin. Pemasukan yang dijadikan salah satu tumpuan pemerintah adalah pajak. Dengan jumlah penduduk yang banyak diharapkan pemerintah akan mendapatkan suatu jumlah pendapatan yang lumayan banyak. Sehingga pemerintah dapat melakukan pembangunan negara tersebut dan akhirnya dinikmati oleh masyarakat. Sehingga pajak dapat dikatakan sebagai sumber penghasilan negara.

Indonesia menerapkan pemungutan pajak terhadap masyarakatnya dengan harapan masyarakat akan menerima fungsi dari pembayaran pajaknya. Hal tersebut dapat dijelaskan bahwa pajak digunakan untuk membiayai berbagai macam infrastuktur dan fasilitas masyarakat guna memperlacar kegiatan perekonomian masyarakat sehingga kesejahteraan masyarakat menajdi meningkat. Sehingga Pajak mempunyai peran yang sangat penting untuk negara guna mendanai kebutuhan negara baik kebutuhan rutin maupun kebutuhan pembangunan. Dalam APBN dijelaskan bahwa penerimaan pajak negara adalah menjadi salah satu pendapatan negara yang terbesar nilainya dan berasal dari dalam negeri. Sehingga pemerintah berharap wajib pajak melakukan pembayaran pajak kepada negara. Dikarenakan pendapatan yang berupa pajak tersebut dapat dimanfaatkan untuk pembangunan infrastruktur dan membayar kebutuhan negara.

Hal tersebut sangat bertolak belakang dengan wajib pajak. Wajib pajak memperlakukan pajak sebagai beban dan beban tersebut akan mengurangi laba bersih perusahaan. WP Badan wajib melunasi pajak dan hal tersebut berarti akan mengurangi laba bersih Wajib Pajak. Sedangkan dari pihak pemerintah pendapatan diperlukan untuk mendanai pengeluaran pemerintah yang sebagian bersumber dari penerimaan pajak. Pajak sebagai pendapatan untuk membiayai pengeluaran pemerintah.

Perbedaan kepentingan tersebut menimbulkan perlawanan antara perusahaan sebagai wajib pajak dan pemerintah sebagai penerima pajak. Perlawanan ini merupakan hambatan dalam pemungutan pajak. WP Badan mempunyai kepentingan bagaimana perusahaan melakukan pembayaran pajak sekecil mungkin. Hal tersebut dikarenakan pajak dapat berakibat pada pengurangan laba bersih perusahaan, yang dikarenakan pajak merupakan beban dalam perusahaan. Hal tersebut merupakan tindakan yang dapat dikatan tidak patuh, karena melaporkan laporan yang tidak semestinya atau tidak sebenarnya kepada kantor pajak.

Bertolak belakang dengan pemerintah yang menganggap pajak adalah sebagai pendapatan yang dapat digunakan untuk pembiayaan pengeluaran negara. Dengan pemikiran wajib pajak yang melakukan pembayaran pajak seminim mungkin maka hasilnya akan bertolak belakang dengan kepentingan pemerintah yang mengharapkan wajib pajak melakukan kewajibannya untuk melakukan pembayaran pajaknya.

Menurut Rahayu (2013) ketidakpatuhan masyarakat dalam hal memberikan pelaporan pajaknya dapat dikarenakan oleh kelemahan dari system pembayaran pajak yang diberlakukan di negara tersebut. Indonesia menggunakan cara Self-assessment system dalam pembayaran pajak. Sistem ini mempunyai arti bahwa wajib pajak dipercaya untuk melakukan semuanya sendiri. Kegiatan dari mulai menghitung, menyetor, mengisi dan melaporkan pajaknya sendiri, semua hal tersebut dilakukan secara mandiri. Dari sistem tersebut dapat menimbulkan permasalahan. Diantaranya adalah permasalahan penyelewengan, pelanggaran dan penyalahgunaan dalam mengurus administrasi dan birokrasi yang berhubungan dengan pajak. Berawal dari hal tersebut maka usaha yang dilakukan pemerintah adalah melakukan tindakan pemeriksaan dan penyelidikan pajak agar wajib pajak terbentuk perilaku patuh dan taat pada pajak. Hal tersebut dapat berdampak pada peningkatan pendapatan pajak negara.

Masyarakat Indonesia dalam hal ini masih mempunyai nilai tingkat kepatuhan dan ketaatan pada pajak dengan poin nilai masih rendah. Sedangakn hal yang demikian bisa diamati 
dari tingkat Rasio Pajak di Indonesia sebesar 10,3 \%. Sedangkan hal yang demikian masih amat rendah jika diperbandingkan dengan negara lainnya seperti negara Malaysia, Vietnam dan Singapura. Malaysia pada saat ini mempunyai nilai rasio menembus angka $13 \%$. Berbeda halnya dengan Vietnam yang telah sampai hingga $16 \%$ demikian juga dengan Singapura. Sehingga dapat dijelaskan dengan rendahnya kepatuhan pajak masyarakat Indonesia akan berakibat pada daya finansial dan akan memberi pengaruh pada perkembangan perekonomian nasional.

Melihat dari keadaan tersebut dapat dikatakan bahwa Indonesia mempunyai kekuatan finansial yang kurang untuk membangun negara ini menjadi lebih baik dibandingkan dengan negara-negara tetangga. Masyarakat termasuk pelaku usaha sehingga masyarakat seharusnya mempunyai kesadaran yang tinggi untuk melakukan pembayaran dan pelaporan pajak. Agar dapat meningkatkan penerimaan pajak maka pemerintah harus melakukan reformasi perpajakan untuk meningkatkan tas rastio. Hal tersebut merupakan tantangan bagi Ditjen Pajak dan seluruh masyarakat Indonesia baik investor, pengusaha ataupun pemerintah (kompas.com).

Usaha untuk meningkatkan penerimaan pajak salah satunya dengan sistem mengerjakan pemeriksaan pajak kepada wajib pajak. Pemeriksa pajak dilaksanakan oleh DJP. Fiskus melaksanakan pemeriksa pajak yang melayani pemeriksaan pajak terhadap Wajib Pajak pada pelaporan SPT dan tak jarang dilaksanakan pemeriksaan pajak yaitu WP Badan. Hal yang demikian dilaksanakan dikarenakan penerimaan $\mathrm{PPh}$ Badan diukur lebih besar diperbandingkan dengan PPh lainnya (Dewi dan Supadmi, 2014).

KPP Pratama Semarang Barat merupakan tempat dilakukannya penelitian ini. Kantor tersebut merupakan salah satu instansi yang bertanggungjawab mengumpulkan dana yang berasal dari pajak dengan jangkauan wilayah kerja Semarang Barat. Berikut mengenai data jumlah pemeriksaan pajak dan jumlah pelaporan SPT tahun 2013 - 2017.

Tabel 1. Surat Perintah Pemeriksaan dan Surat Pemberitahuan Pajak Tahun $2013-2017$

\begin{tabular}{ccc}
\hline Periode & $\begin{array}{c}\text { Pemeriksa } \\
\text { Pajak }\end{array}$ & $\begin{array}{c}\text { Surat Pemberitahuan } \\
\text { Pajak (SPT) Badan }\end{array}$ \\
\hline 2013 & 287 & 2.868 \\
2014 & 285 & 3.161 \\
2015 & 209 & 4.364 \\
2017 & 609 & 3.615 \\
2017 & 657 & 3.897 \\
\hline
\end{tabular}

Berdasarkan tabel 1 tersebut menunjukkan jumlah surat pemberitahuan wajib pajak yang dilaporkan wajib pajak tahun 2013 - 2017 terlihat mengalami ketidakstabilan. Berdasarkan tabel tersebut dapat menggambarkan masih rendahnya tingkat kepatuhan wajib pajak di KPP Semarang Barat. Hal tersebut perlu dilaksanakan upaya penilaian pemeriksa pajak pada KPP Pratama Semarang Barat.

Berdasarkan pada tabel 2 berikut ini dapat diperhatikan bahwa jumlah WP Badan mengalami peningkatan. Hal tersebut dapat menjadikan salah satu penyebab diambilnya lokasi ini. Alasan tersebut karena KPP Pratama Semarang Barat merupakan salah satu tempat pembayaran pajak yang WP Badannya mengalami peningkatan dalam hal jumlahnya hapir setiap tahunnya.

Tabel 2. Jumlah WP Badan KPP Pratama Semarang Barat per 2017

\begin{tabular}{cccccc}
\hline \multirow{2}{*}{ Keterangan } & \multicolumn{5}{c}{ Tahun } \\
\cline { 2 - 6 } & $\mathbf{2 0 1 3}$ & $\mathbf{2 0 1 4}$ & $\mathbf{2 0 1 5}$ & $\mathbf{2 0 1 6}$ & $\mathbf{2 0 1 7}$ \\
\hline Jumlah WP Badan & 8.558 & 9.244 & 10.063 & 10.930 & 11.723 \\
\hline
\end{tabular}


Dari tabel 2 diatas dapat menggambarkan bahwa Wajib Pajak yang terdaftar terus mengalami kenaikan setiap tahunnya. Namun dengan waktu yang bersamaan dapat menggambarkan bahwa daerah tersebut belum mengalami pemaksimalan penarikan pajak seperti yang ditargetkan. Hal ini menampilkan fenomena, bahwa terdapat indikasi adanya ketidakpatuhan dalam melakukan pembayaran pajak yang seharusnya, untuk memenuhi kewajiban wajib pajak dalam melunasi pajak. Berlandaskan uraian diatas, maka penulis ingin meneliti apakah pemeriksa pajak, kesadaran, dan kualitas pelayanan pajak mempunyai pengaruh pada kepatuhan WP Badan dalam memenuhi kewajiban pajaknya pada KPP Pratama Semarang Barat.

\section{TINJAUAN PUSTAKA}

\section{Theory Reasoned Action (TRA)}

Theory of Reasoned Action diperkenalkan oleh Atjzen pada tahun 1980 (Jogiyanto, 2007) materi ini direncanakan menerapkan asumsi bahwa seseorang bersikap dengan metode yang sadar dan menimbang-nimbang segala informasi yang ada. Menurut Jogiyanto (2007) dalam teori ini, Atjzen (1980) mengatakan tindakan akan dilakukan atau tidak oleh seseorang itu merupakan suatu perilaku yang bergantung dari keinginan yang dimiliki oleh orang tersebut. Teori ini menyebutkan bahwa perilaku berasal dari formasi keinginan yang spesifik untuk bertindak, jadi teori keinginan bertindak tidak berupaya memprediksikan perilaku seseorang, tapi keinginan untuk berbuat (Mowen dan Minor dalam Munandar, 2014).

Keyakinan, sikap, niat dan perilaku bergabung dalam teori Theory of Reasoned Action. Niat ialah alat ukur terbaik yang digunakan dalam menilai perilaku seseorang. Hal tersebut dapat dijelaskan apabila kita berharap ingin mengetahui apa yang akan dikerjakan seseorang, metode yang terbaik adalah mencari tau keinginan atau niat dari orang tersebut. Tetapi yang terjadi adalah banyak orang yang melakukan sesuatu dengan membuat pertimbangan dengan alasan-alasan yang sama sekali berbeda atau tidak selalu berdasarkan niat orang tersebut.

\section{Pengertian Pajak}

Berdasarkan UU pasal 1 ayat (1) UU nomor 16 tahun 2009 pengganti UU nomor 5 tahun 2008 yakni perubahan keempat atas UU nomor 6 tahun 1983 perihal syarat, peraturan umum dan tata cara perpajakan. Peraturan tersebut menjelaskan bahwa pajak adalah suatu sumbangan masyarakat yang wajib diberikan kepada negara. Dimana kewajiban dari setiap wajib pajak tersebut baik perorangan maupun perusahaan, mempunyai sifat yang wajib dibayar karena dilandasi dengan aturan perundang-undangan. Demikian pula pembayaran kewajiban tersebut tidak akan mendapatkan imbal jasa yang dapat timbul secara langsung dan diterapkan untuk kepentingan dan kemakmuran rakyat.

Berdasarkan Mardiasmo (2011) Pajak ialah iuran yang dibayar masyarakat kepada pemerintah yaitu ke kas Negara dan diatur menurut peraturan perundangan sehingga mempunyai sifat dapat dipaksakan. Iuran tersebut tidak dapat menghasilkan pendapatan yang segera dapat diterima dan dapat diterapkan untuk pembayaran pengeluaran. Manfaat pajak menurut Resmi (2016) yaitu sebagai a) Manfaat Budget yang artinya Pajak mempunyai manfaat penganggaran dimana pajak dapat mengungkapkan suatu sumber penghasilan pemerintah yang dipergunakan untuk membiaya pengeluaran rutin dan pembangunan. b) Manfaat Regularend yang berarti Pajak mempunyai manfaat yang dapat mengendalikan. Dapat dijelaskan juga bahwa pajak diciptakan untuk mengelola atau mewujudkan kebijakan pemerintah baik di bidang social, ekonomi dan menuju tujuan tertentu kecuali bidang keuangan.

\section{Sistem Pemungutan Pajak}

Berdasarkan Resmi (2016) dapat dijelaskan dengan cara dibagi 3 (tiga) bagian yakni Sistem Penilaian Resmi (Official Assessment System), Sistem Penilaian Diri (Self Assessment 
System), dan Sistem Holding (With Holding System). Dari ketiga system tersebut akan dijelaskan pengertiannya pada uraian dibawah ini.

Pertama yaitu berdasarkan Sistem Penilaian Resmi, dalam sistem ini pemerintah memberikan tanggungjawab kepada petugas pajak untuk melakukan pemungutan pajak. Dimana petugas pajak tersebut melakukan perhitungan jumlah pajak yang harus dibayar wajib pajak setiap tahunnya sesuai dengan aturan pajak yang diberlakukan saat itu. Dalam sistem ini petugas pajak tersebut mempunyai tugas dari mulai menghitung sampai dengan memungut pajak. Dengan demikian sukses atau tidaknya suatu proses pemungutan pajak bergantung pada petugas perpajakan dari pemerintah yang ditunjuk tersebut. Sehingga dapat disimpulkan dalam sistem ini peranan yang paling utama ada pada petugas perpajakan dari pemerintah.

Sedangkan sistem yang kedua yaitu Sistem Penilaian Diri, dalam sistem ini pemungutan pajak difokuskan pada wajib pajak itu sendiri. Dapat dijelaskan wajib pajak disini diberikan kepercayaan untuk menetapkan sendiri jumlah pajak yang harus dibayar atau jumlah pajak terutang untuk setiap tahunnya dan sesuai dengan aturan yang berlaku dalam perundangundangan. Disini wajib pajak dianggap mampu untuk mengerjakan sendiri mulai dari menghitung, sampai dengan melaporkan pajaknya. Selain itu wajib pajak dianggap mampu untuk memahami aturan pajak yang sedang berlaku dan cara penghitungannya. Disini dalam system ini dijunjung tinggi sifat kejujuran karena sangat dipercaya dalam segala halnya. Selain itu pemerintah juga percaya akan kesadaran wajib pajaknya untuk melakukan pembayaran pajaknya secara tepat waktu.

Sistem yang ketiga yaitu Sistem Holding. Dalam system Holding ini pemerintah membutuhkan pihak lain untuk melakukan pemungutan pajaknya. Pemungut pajak atau dalam hal ini adalah pemerintah, memberikan kewenangan kepada pihak ketiga untuk melakukan tugas pemungutan pajak. Pihak ketiga disini mempunyai kewenangan meliputi dari penghitungan besarnya pajak dengan nilai sesuai dengan peraturan perpajakan. Pihak ketiga yang ditunjuk pemerintah tersebut penunjukkanya dilakukan sesuai dengan perundangundangan, peraturan pemerintah ataupun dengan keputusan presiden. Serta aturan lain yang bertujuan intinya pihak ketiga tersebut untuk melakukan memotong, memungut, menyetor serta memberikan evaluasi dan bertanggungjawab melalui sarana perpajakan. Dapat dikatakan dalam system ini sukses atau tidak suksesnya pelaksanaan sistem pemungutan pajak akan sangat bergantung pada pihak ketiga yang ditunjuk.

\section{Pemeriksa Pajak}

Pemeriksa pajak dijelaskan dalam UU nomor 16 tahun 2009 substitusi UU nomor 5 tahun 2008 mengenai perubahan yang keempat atas UU nomor 6 tahun 1983. Undang-undang tersebut menjelaskan mengenai perihal Ketetapan Umum dan Tata Cara Perpajakan.

Berdasarkan Rahayu (2013) pemeriksa pajak merupakan suatu hal pengawasan melaksanakan self assesment untuk melaksanakan dari wajib pajak, yang seharusnya berpegang teguh pada UU perpajakan. Petugas pemeriksa pajak diatur dalam Surat Keputusan Menteri Keuangan No. 17/PMK 03/2013. Dalam surat keputusan tersebut dijelaskan bahwa petugas pemeriksa pajak adalah PNS yang berasal dari Dirjen Pajak yang ditunjuk untuk melaksanakan tugas kegiatan pemeriksaan.

\section{Kesadaran Perpajakan}

Kesadaran pajak ialah kesadaran diri yang tidak memaksa untuk melunasi kewajiban pajaknya. Kesadaran pajak memberikan pengetahuan mengenai peraturan pajak, melakukan peraturan pajak secara benar dan sukarela. Wajib Pajak agar menyadari pajaknya yang pasti akan mematuhi ketentuan pajak yang telah ada, wajib pajak akan menghitung jumlah pajaknya dengan benar, dan akan melunasi hutang pajaknya (Nugroho, 2012).

Kesadaran merupakan kondisi mengenal atau mengerti, meskipun perpajakan 
merupakan tentang seputar pajak. Sehingga kesadaran pajakan ialah keadaan mengenal atau paham perihal mengenai pajak. Pengukuran yang bersifat positif oleh wajib pajak terhadap petugas pajak yang ditunjuk oleh pemerintah akan mendorong masyarakat untuk mematuhi dan melaksanakan kewajiban wajib pajak agar melakukan pembayaran pajaknya. Oleh sebab itu kesadaran wajib pajak mengenai pembayaran pajak dibutuhkan untuk dapat meningkatkan kepatuhan Wajib Pajak (Jatmiko, 2012).

Sehingga dengan kata lain kesadaran Wajib Pajak adalah seseorang yang merupakan wajib pajak mempunyai keadaan mengenal, mengerti dan memahami mengenai seputar perpajakan. Tidak hanya itu saja tetapi wajib pajak juga melaksanakan penghitungan dengan benar, melakukan pembayaran dengan tepat atau dapat dikatakan tidak terlambat. Karena jikalau wajib pajak hanya sampai pada mengerti dan memahami tetapi tidak melakukan tindakan yang dimengerti tersebut berarti masih dapat dikatakan tidak sadar dalam hal perpajakan. Dengan kata lain kesadaran Wajib Pajak benar-benar dibutuhkan kesadarannya untuk melakukan pembayaran kewajibannya. Kesadaran yang demikian akan mengakibatkan kepatuhan wajib untuk melaksakanan kewajibannya membayar pajak akan tercapai. Hal tersebut berakibat pada minat pembayar pajak akan terus mengalami peningkatan dan tidak ada lagi masyarakat yang tidak membayar pajaknya.

\section{Kualitas Pelayanan}

Berdasarkan Utami, dkk. (2012) kualitas pelayanan mempunyai arti yaitu suatu kondisi dimana keadaan mempunyai sifat yang dapat berubah-ubah dan dapat mempengaruhi barang, jasa, manusia, proses dan lingkungan. Dimana hal tersebut dapat terpenuhi dan hasilnya melebihi harapan. Tetapi dalam kamus Bahasa Indonesia pelayanan mempunyai arti sebagai cara membantu keperluan orang lain sehingga orang tersebut merasakan kepuasan atau terbantu dengan pelayanan kita.

Sehingga dapat disimpulkan bahwa kualitas pelayanan dari petugas pajak dapat mempunyai arti sebagai suatu kondisi dimana masyarakat dalam hal ini adalah wajib pajak dapat memberikan penilaian terhadap pelayanan yang diberikan oleh petugas pajak. Penilaian tersebut dapat berupa penilaian positif ataupun negative. Sehingga akan memunculkan persepsi wajib pajak menilai pelayanan yang diberikan aparat pajak. Menurut Dewi \& Supadmi (2013) menjelaskan mengenai kualitas adalah keadaan yang dapat berubah yang terkait dengan produk, jasa manusia, proses, dan lingkungan yang dapat memenuhi harapan dari pihak yang menginginkannya.

\section{Kepatuhan Wajib Pajak}

Berdasarkan Kamus Umum Bahasa Indonesia (2017) kepatuhan mempunyai arti tunduk dengan aturan. Pada perpajakan mempunyai arti bahwa ketaatan pajakan ialah kewajiban, patuh dan wajib serta melaksanakan ketetapan perpajakan. Berdasarkan Gunadi (2013) pengertian dari kepatuhan wajib pajak ialah keadaan dimana seseorang yang merupakan wajib pajak tersebut mempunyai rasa bersedia untuk melakukan tanggungjawab membayar pajaknya sesuai dengan peraturan yang berlaku. Bahkan keadaan dari orang tersebut yang merupakan wajib pajak tanpa perlu dilakukan pemeriksaan, dipantau bahkan tanpa diberikan peringatan, ancaman baik peraturan ataupun administrasi. Berdasarkan Machfud Sidik dalam Rahayu (2013) kepatuhan perpajakan adalah kepatuhan yang memenuhi kewajiban perpajakannya secara sukarela. Berdasarkan Safri Nurmantu dalam Rahayu (2013) menyatakan bahwa kepatuhan perpajakan adalah keadaan dimana orang tersebut yaitu wajib pajak melakukan pambayaran semua pajak yang harus dibayarnya. 


\section{WP Badan}

Wajib pajak pengertiannya diatur dalam UU No.16 Tahun 2009. Mengenai Perubahan Ketiga atas UU No.6 Tahun 1983 tentang Ketentuan Umum Perpajakan dan Tata Cara Perpajakan. Wajib pajak merupakan masyarakat yang dapat berupa individu atau perusahaan berupa badan, yang mempunyai kepentingan mengenai pembayaran, pemotongan, serta memiliki hak dan kewajiban mengenai perpajakan yang tidak melanggar ketetapan dan aturan perundang-undangan perpajakan (Rosdiana dan Irianto, 2015).

WP Badan berdasarkan pernyataan Resmi (2016) adalah sekelompok orang atau dan modal yang mengungkapkan persatuan publik untuk menjalankan bisnis atau tidak menjalankan bisnisnya melalui perseoran terbatas, perseoran komandetir, perseoran lainnya, BUMN atau BUMD. Dari pengertian diatas maka dapat dijelaskan mengenai pengertian WP Badan yaitu berupa sekelompok orang atau modal yang wajib melaksanakan pembayaran pajak termasuk memungut atau memotong pajak tertentu.

\section{Kerangka Konseptual}

Berikut ini merupakan kerangka konseptual dari penelitian ini yang dapat dijelaskan melalui gambar 1 berikut ini.

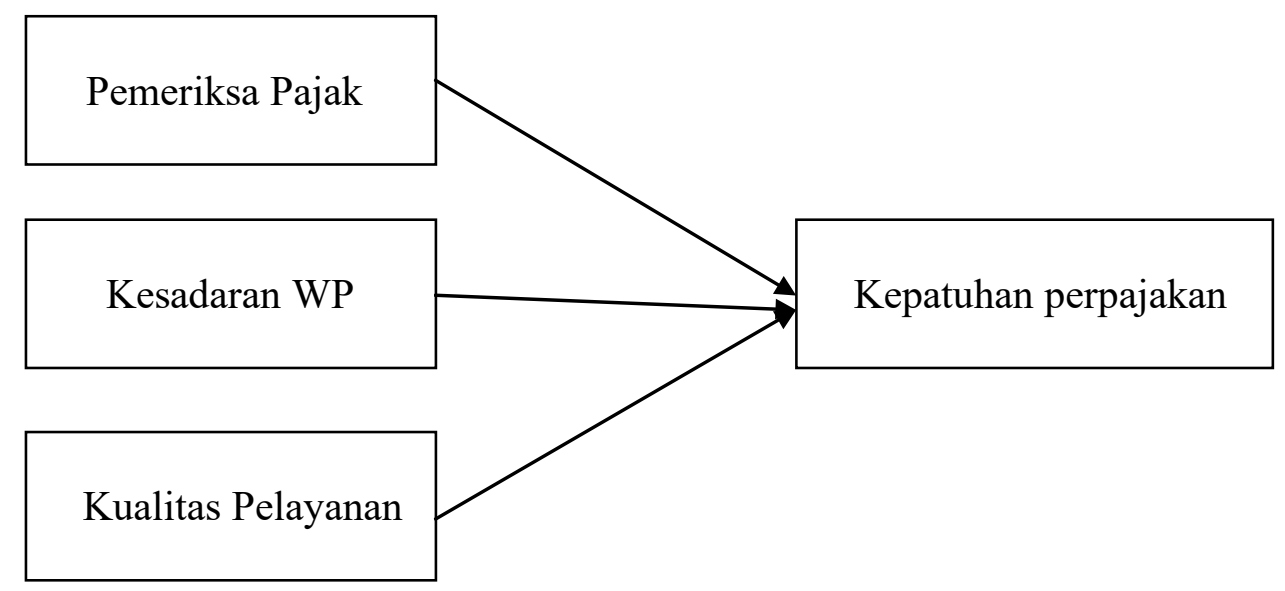

\section{Gambar 1. Kerangka Konseptual}

\section{METODE PENELITIAN}

Populasi yang dipergunakan dalam penelitian adalah WP Badan yang terdaftar di KPP Pratama Semarang Barat dengan jumlah populasi pada tahun 2018 sebanyak 11.723 WP Badan. Sedangkan metode pengambilan sampel menggunakan Simple Random Sampling. Cara menentukan besarnya sample, peneliti menggunakan Rumus Slovin dan diperoleh nilai sebesar 100. Sehingga sampel yang digunakan dalam penelitian ini adalah 100 responden yakni WP Badan terdaftar di KPP Pratama Semarang Barat.

Jenis dan sumber data yang dipergunakan dalam penelitian ini adalah data primer. Data pada penelitian ini diperoleh dengan cara langsung dari sumbernya yaitu WP Badan yang terdaftar pada KPP Pratama Semarang Barat melalui pengisian kuesioner yang selanjutnya akan dihitung menggunanakan regresi linear berganda. Analisis data yang dipergunakan adalah dengan bantuan program SPSS.

Teknik analisis data diperlukan memakai regersi linier berganda, untuk penguji hasil variabel independen kepada variabel dependen, dengan memakai aplikasi SPSS. Teknik analisis regresi berganda yang dipakai mempunyai persamaan sebagai berikut ini :

$$
\mathbf{Y}=\alpha+\boldsymbol{\beta}_{1} \mathbf{X}_{1}+\boldsymbol{\beta}_{2} \mathbf{X}_{2}+\boldsymbol{\beta}_{3} \mathbf{X}_{3}+\mathbf{e}
$$


Keterangan :

\begin{tabular}{|c|c|}
\hline Y & $=$ Kepatuhan Perpajakan \\
\hline$\alpha$ & $=$ Konstanta \\
\hline$\beta_{1} \beta_{2} \beta_{3}$ & $=$ Koefisien regresi \\
\hline $\mathrm{X}_{1}$ & $=$ Pemeriksa Pajak \\
\hline $\mathrm{X}_{2}$ & $=$ Kesadaran Wajib Pajak \\
\hline$X_{3}$ & $=$ Kualitas Pelayanan \\
\hline & $=$ error \\
\hline
\end{tabular}

HASIL DAN PEMBAHASAN

Pengujian Instrumen

\section{Uji Validitas}

Dalam penelitian ini peneliti membagi kuesioner terhadap 100 responden, sedangkan hasil uji validitasnya valid semua. Dimana $r$ hitung mempunyai hasil diatas dari nilai $r$ tabelnya.

Tabel 3. Hasil Uji Validitas

\begin{tabular}{|c|c|c|c|c|}
\hline Variabel & Indikator & $\begin{array}{c}\mathbf{R} \\
\text { Tabel }\end{array}$ & $\begin{array}{c}\mathbf{r} \\
\text { Hitung }\end{array}$ & Ket \\
\hline \multirow{5}{*}{$\begin{array}{l}\text { Kepatuhan } \\
\text { perpajakan } \\
\quad(Y)\end{array}$} & Melaporkan sebagai wajib pajak. & 0,197 & 0.581 & Valid \\
\hline & Mengisi SPT secara lengkap. & 0,197 & 0.672 & Valid \\
\hline & Membayar pajak terutang. & 0,197 & 0.747 & Valid \\
\hline & $\begin{array}{l}\text { Membayar pajak sesuai dengan } \\
\text { jumlahnya. }\end{array}$ & 0,197 & 0.723 & Valid \\
\hline & Tidak pernah memiliki tunggakan. & 0,197 & 0.457 & Valid \\
\hline \multirow[t]{5}{*}{$\begin{array}{l}\text { Pemeriksa } \\
\text { pajak }\left(\mathrm{X}_{4}\right)\end{array}$} & $\begin{array}{l}\text { Pemeriksa pajak memiliki } \\
\text { pengetahuan dan keahlian pajak. }\end{array}$ & 0,197 & 0.671 & Valid \\
\hline & $\begin{array}{l}\text { Pemeriksa pajak dituntut untuk } \\
\text { selalu jujur dalam memeriksa WP. }\end{array}$ & 0,197 & 0.610 & Valid \\
\hline & $\begin{array}{l}\text { Pemeriksa pajak tunduk kode etik } \\
\text { yang berlaku. }\end{array}$ & 0,197 & 0.473 & Valid \\
\hline & $\begin{array}{l}\text { Pemeriksa memiliki sikap } \\
\text { independen. }\end{array}$ & 0,197 & 0.689 & Valid \\
\hline & $\begin{array}{l}\text { Pemeriksa pajak memiliki } \\
\text { pendidikan setara. }\end{array}$ & 0,197 & 0.671 & Valid \\
\hline \multirow{4}{*}{$\begin{array}{l}\text { Kesadaran } \\
\text { wajib pajak } \\
\quad\left(\mathrm{X}_{1}\right)\end{array}$} & $\begin{array}{l}\text { Pajak merupakan bentuk partisipasi } \\
\text { dalam menunjang pembangunan }\end{array}$ & 0,197 & 0.328 & Valid \\
\hline & $\begin{array}{l}\text { Negara. } \\
\text { Penundaan pembayaran pajak dan } \\
\text { pengurangan beban pajak sangat } \\
\text { merugikan Negara. }\end{array}$ & 0,197 & 0.550 & Valid \\
\hline & $\begin{array}{l}\text { Pajak ditetapkan dengan undang- } \\
\text { undang dan dapat dipaksakan. }\end{array}$ & 0,197 & 0.532 & Valid \\
\hline & $\begin{array}{l}\text { Membayar pajak tidak sesuai dengan } \\
\text { yang seharusnya dibayar akan } \\
\text { merugikan negara. }\end{array}$ & 0,197 & 0.273 & Valid \\
\hline
\end{tabular}




$\begin{array}{clccc}\begin{array}{c}\text { Kualitas } \\ \text { pelayanan } \\ \left(\mathrm{X}_{2}\right)\end{array} & \begin{array}{l}\text { Sanksi diperlukan untuk } \\ \text { menciptakan kedisiplinan WP } \\ \text { dalam membayar pajak. }\end{array} & 0,197 & 0.542 & \text { Valid } \\ & \begin{array}{l}\text { Sanksi dilaksanakan dengan tegas } \\ \text { kepada WP yang melanggar. }\end{array} & 0,197 & 0.885 & \text { Valid } \\ & \begin{array}{l}\text { Sanksi diberikan sesuai dengan } \\ \text { pelanggaran yang dilakukan. }\end{array} & 0,197 & 0.846 & \text { Valid } \\ \begin{array}{l}\text { Penerapan sanksi harus sesuai } \\ \text { dengan ketentuan dan peraturan } \\ \text { yang berlaku. }\end{array} & 0,197 & 0.885 & \text { Valid }\end{array}$

\section{Uji Reliabilitas}

Berikut merupakan hasil dari reliabilititas data penelitian ini.

Tabel 4. Hasil Uji Relibilitas

\begin{tabular}{llccl}
\hline No & \multicolumn{1}{c}{ Variabel } & $\begin{array}{c}\text { Cronbach } \\
\text { Alpa }\end{array}$ & $\begin{array}{c}\text { Alpha } \\
\text { Standar }\end{array}$ & Keterangan \\
\hline 1. & Kepatuhan & 0.834 & 0,6 & Reliabel \\
2. & Perpajakan & 0.819 & 0,6 & Reliabel \\
3. & Kesadaran WP & 0.634 & 0,6 & Reliabel \\
4. & Kualitas Pelayanan & 0.903 & 0.6 & Reliabel \\
& Pemeriksa Pajak & & & \\
\hline
\end{tabular}

\section{Uji Asumsi Klasik}

\section{Uji Normalitas}

Uji normalitas disini menggunakan uji Kolmogorof Smirnov yang dapat dilihat hasilnya dibawah ini.

Tabel 5. Uji Kolmogorof Smirnov Test

\begin{tabular}{llr}
\hline & & $\begin{array}{c}\text { Unstandardized } \\
\text { Residual }\end{array}$ \\
\hline $\mathbf{N}$ & & 100 \\
Normal Parameters a,b & Mean & 0.0000000 \\
& Std Deviation & 1.21112075 \\
Most Extreme & Absolute & 0.111 \\
Differences & Positive & 0.061 \\
& Negative & -0.111 \\
Kologorof-Smirnov Z & & 1.109 \\
Asimp. Sig. (2-tailed) & & 0.171 \\
\hline
\end{tabular}

\section{Uji Heterokedastisitas}

Hasil uji heteroskedetisitas dapat dilihat pada tabel 6 dibawah ini. Sedangkan uji heterokedastisitas diuji dengan menggunakan uji Glejser, antara lain sebagai berikut : 
Tabel 6. Uji Glejser

\begin{tabular}{|c|c|c|c|c|c|c|}
\hline \multirow{2}{*}{ Moc } & & \multicolumn{2}{|c|}{$\begin{array}{c}\text { Unstandardized } \\
\text { Coefficients }\end{array}$} & \multirow{2}{*}{$\begin{array}{c}\begin{array}{c}\text { Standardized } \\
\text { Coefficients }\end{array} \\
\text { Betta }\end{array}$} & \multirow{2}{*}{$\mathbf{t}$} & \multirow{2}{*}{ Sig. } \\
\hline & & B & $\begin{array}{l}\text { Std. } \\
\text { Error }\end{array}$ & & & \\
\hline \multirow[t]{4}{*}{1} & (Constant) & 0.385 & 0.628 & & 0.614 & 0.541 \\
\hline & Pemeriksa_Pajak & -0.044 & 0.034 & -0.156 & 1.302 & 0.196 \\
\hline & Kesadaran & 0.060 & 0.047 & 0.172 & 1.264 & 0.209 \\
\hline & Kualitas_Pelayanan & 0.031 & 0.031 & 0.118 & 0.977 & 0.331 \\
\hline
\end{tabular}

\section{Uji Multikolinieritas}

Hasil pengujian multikolinieritas memberitahukan kalau all variabel independen mempunyai nilai VIF di bahwa angka 10 dan batas tolerance lebih dari 0,10 dapat dinyatakan tidak adanya mutlikolinearitas antara variabel bebas. Untuk hasil seluruhnya bisa dilihat dari tabel 7.

Tabel 7. Uji Multikolinearitas

\begin{tabular}{|c|c|c|c|c|c|c|c|c|}
\hline \multirow{2}{*}{ Model } & & \multicolumn{2}{|c|}{$\begin{array}{l}\text { Unstandardized } \\
\text { Coefficients }\end{array}$} & \multirow{2}{*}{$\begin{array}{c}\begin{array}{c}\text { Standardized } \\
\text { Coefficients }\end{array} \\
\text { Betta } \\
\end{array}$} & \multirow{2}{*}{$\mathbf{t}$} & \multirow{2}{*}{ Sig. } & \multicolumn{2}{|c|}{$\begin{array}{c}\text { Collinearity } \\
\text { Statist }\end{array}$} \\
\hline & & B & $\begin{array}{l}\text { Std. } \\
\text { Error }\end{array}$ & & & & $\begin{array}{l}\text { Toleranics } \\
\text { ce }\end{array}$ & VIF \\
\hline \multirow[t]{4}{*}{1} & (Constant) & 2.866 & 0.981 & & 2.922 & 0.004 & & \\
\hline & Pemeriksa Pajak & 0.498 & 0.053 & 0.552 & 9.370 & 0.000 & 0.693 & 1.444 \\
\hline & Kesadaran_WP & 0.372 & 0.074 & 0.337 & 5.021 & 0.000 & 0.533 & 1.876 \\
\hline & Kualitas_Pelayanan & 0.130 & 0.049 & 0.157 & 2.642 & 0.010 & 0.680 & 1.470 \\
\hline
\end{tabular}

\section{Metode Analisis Data}

\section{Analisis Regresi Linear Berganda}

Berdasarkan data yang ada berikut ini adalah hasil melalui proses perhitungan SPSS dan dapat diperoleh hasil Regresi Linier Berganda sebagai berikut :

Tabel 8. Hasil Pengolahan Data Regresi Linier Berganda

\begin{tabular}{|c|c|c|c|c|c|c|c|c|}
\hline \multirow[t]{2}{*}{ Model } & & \multicolumn{2}{|c|}{$\begin{array}{c}\text { Unstandardized } \\
\text { Coefficients }\end{array}$} & \multirow{2}{*}{$\begin{array}{c}\text { Standardized } \\
\text { Coefficients } \\
\text { Betta }\end{array}$} & \multirow[t]{2}{*}{$\mathbf{t}$} & \multirow[t]{2}{*}{ Sig. } & \multicolumn{2}{|c|}{$\begin{array}{c}\text { Collinearity } \\
\text { Statist }\end{array}$} \\
\hline & & B & $\begin{array}{l}\text { Std. } \\
\text { Error }\end{array}$ & & & & Tolerance & VIF \\
\hline 1 & (Constant) & 2.866 & 0.981 & & 2.922 & 0.004 & & \\
\hline & Pemeriksa Pajak & 0.498 & 0.053 & 0.552 & 9.370 & 0.000 & 0.693 & 1.444 \\
\hline & Kesadaran_WP & 0.372 & 0.074 & 0.337 & 5.021 & 0.000 & 0.533 & 1.876 \\
\hline & Kualitas_Pelayanan & 0.130 & 0.049 & 0.157 & 2.642 & 0.010 & 0.680 & 1.470 \\
\hline
\end{tabular}

Pada hasil tersebut, menghasilkan persamaan regresi linier berganda dibawah ini:

$$
Y=2,888+0,498 X_{1}+0,372 X_{2}+0,130 X_{3}
$$

Persamaan tersebut dapat diartikan bahwa semua varaibel indpenden terpengaruh signifikan kepada variabel dependen secara parsial, di mana $\mathrm{X}_{1}$ (Pemeriksa Pajak), $\mathrm{X}_{2}$ (Kesadaran Wajib Pajak) dan $\mathrm{X}_{3}$ (Kualitas Pelayanan) masing-masing berpengaruh positif terhadap Y (Kepatuhan Wajib Pajak). 
Belia Natasya Putri dan Ira Septriana : Tingkat Kepatuhan WP Badan Dalam Memenuhi Kewajiban Perpajakannya Melalui Pemeriksa Pajak, Kesadaran Dan Kualitas Pelayanan Pada KPP Pratama Semarang Barat

\section{Uji Hipotesis}

Uji F

Uji F digunakan untuk mengetahui adanya pengaruh antara Pemeriksa Pajak, Kesadaran Wajib Pajak, dan Kualitas Pelayanan Perpajakan secara simultan terhadap Kepatuhan perpajakan (Y). Berikut ini merupakan hasil dari SPSS.

Tabel 9. Uji F

\begin{tabular}{llccccc}
\hline \multicolumn{1}{c}{ Model } & $\begin{array}{c}\text { Sum of } \\
\text { Squares }\end{array}$ & Df & $\begin{array}{c}\text { Mean } \\
\text { Square }\end{array}$ & F & Sig. \\
\hline $\mathbf{1}$ & Regression & 483.025 & 3 & 161.008 & 106.441 & $0.000 \mathrm{a}$ \\
& Residual & 145.215 & 96 & 1.513 & & \\
& Total & 628.240 & 99 & & & \\
\hline
\end{tabular}

\section{Uji t}

Uji t diperlukan untuk melihat signifikansi pengaruh Pemeriksa pajak, Kesadaran, dan Kualitas pelayanan Perpajakan secara parsial terhadap Kepatuhan perpajakan. Adapun tabel pengujian hipotesis t bisa dijelaskan ini :

Tabel 10. Uji t

\begin{tabular}{|c|c|c|c|c|c|c|c|c|}
\hline \multirow{2}{*}{ Model } & & \multicolumn{2}{|c|}{$\begin{array}{c}\text { Unstandardized } \\
\text { Coefficients }\end{array}$} & \multirow{2}{*}{$\begin{array}{c}\begin{array}{c}\text { Standardized } \\
\text { Coefficients }\end{array} \\
\text { Betta }\end{array}$} & \multirow{2}{*}{$\mathbf{t}$} & \multirow{2}{*}{ Sig. } & \multicolumn{2}{|c|}{$\begin{array}{c}\text { Collinearity } \\
\text { Statist }\end{array}$} \\
\hline & & B & $\begin{array}{l}\text { Std. } \\
\text { Error }\end{array}$ & & & & Tolerance & VIF \\
\hline \multirow[t]{4}{*}{1} & (Constant) & 2.866 & 0.981 & & 2.922 & 0.004 & & \\
\hline & Pemeriksa Pajak & 0.498 & 0.053 & 0.552 & 9.370 & 0.000 & 0.693 & icł. .444 \\
\hline & Kesadaran_WP & 0.372 & 0.074 & 0.337 & 5.021 & 0.000 & 0.533 & 1.876 \\
\hline & Kualitas_Pelayanan & 0.130 & 0.049 & 0.157 & 2.642 & 0.010 & 0.680 & 1.470 \\
\hline
\end{tabular}

\section{Koefisien Determinasi $\left(\mathbf{R}^{\mathbf{2}}\right)$}

Nilai koefisien determenasi berfungsi untuk memberitahu seberapa tinggi kemampuan model dalam memberikan variasi variabel dependen. Hasil Output SPSS dari Koefisien determinasi bisa dilihat pada tabel 11 berikut ini.

Tabel 11. Koefisien Determinasi

\begin{tabular}{lrrrr}
\hline Model & R & $\begin{array}{r}\text { R } \\
\text { Square }\end{array}$ & $\begin{array}{r}\text { Adjusted } \\
\text { R Square }\end{array}$ & $\begin{array}{r}\text { Std. Error of } \\
\text { the Estimate }\end{array}$ \\
\hline $\mathbf{1}$ & $0.877 \mathrm{a}$ & 0.769 & 0.762 & 1.230 \\
\hline
\end{tabular}

\section{PEMBAHASAN}

\section{Pengaruh Pemeriksa Pajak Terhadap Kepatuhan Perpajakan}

Berdasarkan hasil uji statistik bahwa hipotesis pengaruh pemeriksa pajak terhadap kepatuhan perpajakan mempunyai hasil diterima. Dapat diartikan bahwa pemeriksa pajak berpengaruh positif terhadap kepatuhan WP Badan dalam memenuhi kewajiban perpajakannya. Dalam hipotesis ini pemeriksa pajak menggunakan indikator terbesarnya yaitu Pemeriksa pajak wajib mempunyai pengetahuan dan keahlian/kemampuan yang memadai dibidang perpajakan, akuntansi dan pemeriksa pajak. Hal tersebut dapat digambarkan pada besarnya nilai sebesar 4,06 (dengan interval nilai 3,40 - 4,19) yang masuk kedalam kategori baik. Hal ini dapat diartikan bahwa wajib pajak menyatakan bahwa Pemeriksa pajak harus memiliki pengetahuan dan keahlian yang baik dibidang perpajakan, akuntansi dan pemeriksaan. Sedangkan indikator 
terkecil dalam Pemeriksa pajak ialah mempunyai tingkat pendidikan formal minimal D3. Hal tersebut dapat tercermin pada besarnya nilai sebesar 3,78 (dengan interval nilai 3,40-4,19) yang masuk dalam kategori baik. Hal ini dapat diartikan bahwa wajib pajak menyadari bahwa Pemeriksa pajak harus mempunyai tingkat pendidikan formal minimal D3.

Dengan demikian maka teori Theory of Planned Behavior mendukung penelitian ini karena pemeriksa pajak memengaruhi WP Badan untuk patuh. Dengan adanya pemeriksa pajak yang berpendidikan, jujur, independen dan memiliki keahlian dibidang perpajakan, akuntansi dan pemeriksaan dapat menyebabkan kepatuhan WP Badan meningkat dalam memenuhi kewajiban perpajakannya.

Hasil statistik deskriptif dapat dilihat hasilnya yaitu jawaban responden dengn rata-rata nilai paling tinggi untuk variabel Pemeriksa pajak adalah pemeriksa pajak harus memiliki pengetahuan dan keahlian yang memadai di bidang perpajakan, akuntansi dan pemeriksaan. Nilainya yaitu sebesar 4,06 dengan jumlah responden menjawab setuju yaitu sebesar 51 orang. Hal ini menggambarkan bahwa pihak pemeriksa pajak yang menguasai bidang akuntansi, perpajakan dan pemeriksaan dapat mempengaruhi kepatuhan WP Badan. Penelitian ini mempunyai hasil yang sejalan dengan penelitian Dewi dan Supadmi (2014), Layata dan Setiawan (2014), Mandagi (2014) Pranata dan Setiawan (2015) dimana hasilnya menunjukkan bahwa Pemeriksa pajak berpengaruh positif terhadap kepatuhan wajib pajak.

\section{Pengaruh Kesadaran Wajib Pajak Terhadap Kepatuhan Perpajakan}

Berdasarkan hasil uji statistik diperoleh hasil bahwa hipotesis kedua ini diterima. Hal tersebut mempunyai arti bahwa Kesadaran wajib pajak berpengaruh terhadap kepatuhan WP Badan. Menurut data yang didapatkan dari jawaban responden pada kuesioner, secara keseluruhan wajib pajak mempunyai persepsi yang tinggi mengenai Kesadaran wajib pajak terefleksi pada besarnya nilai sebesar 3,77 (dengan interval nilai 3,40-4,19) yang masuk dalam kategori baik.

Kepatuhan wajib pajak dalam penelitian ini indicator terbesarnya adalah Pajak yang akan saya bayarkan sesuai dengan yang harus saya bayar. Hal tersebut dapat dijelaskan pada besarnya nilai rata-rata total yaitu sebesar 3,96 (dengan interval nilai 3,40-4,19) yang masuk sebagai kategori baik. Hal ini bisa diartikan bahwa pajak yang dibayarkan oleh wajib pajak sesuai dengan yang seharusnya dibayar.

Sedangkan indikator terkecil dalam penelitian ini yaitu Saya membayar pajak karena akan dipakai pemerintah untuk pembangunan negara. Hal tersebut dapat digambarkan pada besarnya nilai rata-rata sebesar 3,59 (dengan interval nilai 3,40-4,19) yang masuk dalam kategori baik. Hal tersebut bisa diartikan bahwa wajib pajak menyadari bahwa pajak yang dibayarkan digunakan untuk kepentingan negara.

Kesadaran wajib pajak dari WP Badan yang bagus akan mewujudkan keinginan untuk secara sukarela menghitung, membayar dan melaporkan pajaknya. Hal tersebut diikuti dengan mematuhi peraturan pajak yang berlaku. Oleh karena itu secara langsung akan memberi pengaruh pada kepatuhan dalam pemenuhan wajib pajak di Kantor Pelayanan Pajak Pratama Semaraang Barat. Kesadaran wajib pajak ialah moral yang berasal dari masing-masing individu yang kemungkinan orang lain tidak memilikinya (Ajsen, 2002).

Dalam kaitannya dengan Kesadaran wajib pajak, tidak lepas dengan integritas. Integritas yang dapat berarti bahwa prilaku seseorang konsisten dengan nilai yang menyertainya dan orang tersebut bersifat jujur, etis dan bisa diandalkan. Integritas bisa diartikan sebagai kesehatan tata krama, kejujuran yang terbebas dari dampak atau motif korupsi, bisa dipercaya dan disukai, serta mempunyai ketulusan.

Dengan demikian maka teori Theory Reasoned Action mendukung penelitin ini karena kesadaran wajib pajak memengaruhi WP Badan untuk patuh. Persepsi wajib pajak dalam membuat keputusan mengenai perilaku kepatuhan wajib pajak sesuai dengan penelitian ini 
yaitu indikator yang dominan adalah wajib pajak membayar pajak sesuai dengan yang seharusnya dibayar.

Penelitian ini mempunyai hasil yang sesuai dengan penelitian yang dilakukan oleh Layata dan Setiawan (2014), Dewi dan Supadmi (2014), Pranata dan Setiawan (2015) yang menunjukkan bahwa Kesadaran wajib pajak berpengaruh positif terhadap Kepatuhan perpajakan. Sedangkan hasil penelitian ini juga tidak sesuai dengan penelitian yang dilakukan oleh As'ari dan Erawati (2018) yang menyatakan bahwa Kesadaran wajib pajak tidak berpengaruh terhadap Kepatuhan perpajakan.

\section{Pengaruh Kualitas Pelayanan Terhadap Kepatuhan Perpajakan}

Berdasarkan hasil uji statistik diperoleh bahwa hipotesis ketiga diterima. Hasil tersebut mempunyai arti bahwa Kualitas Pelayanan berpengaruh terhadap kepatuhan perpajakan WP Badan. Dalam penelitian ini kualitas pelayanan memiliki indikator terbesar yaitu Pegawai KPP Pratama memiliki motivasi tinggi sebagai pelayan publik. Hal tersebut tercermin pada besarnya nilai rata-rata total sebesar 3,95 (dengan interval nilai 3,40-4,19) yang masuk kedalam kategori baik. Hal ini dapat diartikan bahwa wajib pajak menyatakan bahwa pegawai KPP memiliki motivasi yang tinggi karena dapat memberikan pelayanan yang baik kepada wajib pajak.

Sedangkan indikator terkecil dalam penelitian ini adalah Pegawai KPP Pratama harus memiliki kompetensi skill, knowledge, experience dalam hal kebijakan perpajakan, administrasi pajak dan perundang-undangan tercermin pada besarnya nilai rata-rata total sebesar 3.59 (dengan interval nilai 3,40-4,19) yang masuk dalam kategori baik. Hal ini dapat mempunyai arti bahwa wajib pajak menyadari bahwa Pegawai KPP Pratama memiliki kompetensi skill, knowledge, experience dalam hal kebijakan perpajakan, administrasi pajak dan perundang-undangan. Kualitas pelayanan yang baik akan membuat WP Badan merasa dihargai dan merasa diberikan fasilitas. Sehingga hal tersebut membuat WP Badan merasa lebih dimudahkan dalam melakukan pemenuhan pajaknya. Maka dampak yang diberikan terhadap Kantor Pelayanan Pajak Pratama Semarang Barat adalah peningkatan kepatuhan dari WP Badannya.

Indikator tempat pelayanan yang memudahkan proses pelayanan menunjukkan hasil yang paling dominan dibandingkan dengan keempat indikator lainnya pada variabel kualitas pelayanan. Hal ini menunjukkan bahwa kenyamanan, cepat tanggap dan efektif dari fiskus memberikan pengaruh pada tingkat kepatuhan WP Badan.

Dengan demikian teori tindakan beralasan mendukung penelitian ini karena kualitas pelayanan berpengaruh pada tingkat kepatuhan WP Badan. Hal tersebut dikarenakan semakin baik kualitas pelayanan pajak maka tingkat kepatuhan wajib pajak dalam memenuhi kewajibannya akan semakin meningkat. Pelayanan yang berkualitas yaitu pelayanan yang dapat memberikan kepuasan dalam pemenuhan kebutuhan dan keinginan wajib pajak sehingga harapan wajib pajak sesuai dengan kenyataan yang diterima.

Hasil penelitian ini sejalan dengan hasil peneltian yang dilakukan oleh Layata dan Setiawan (2014), Pranata dan Setiawan (2015), Dewi dan Supadmi (2014) yang menunjukkan bahwa kualitas pelayanan berpengaruh positif terhadap kepatuhan perpajakan. Hasil penelitian ini juga tidak sejalan dengan hasil penelitian yang dilakukan oleh As'ari dan Erawati (2018) yang menyatakan bahwa kualitas pelayanan tidak berpengaruh terhadap kepatuhan perpajakan.

\section{SIMPULAN}

Berdasarkan pembahasan pada penelitian ini maka dapat ditarik suatu kesimpulan antara lain bahwa Pemeriksa pajak berpengaruh signifikan dan positif terhadap kepatuhan wijb pajak badan dalam memenuhi kewajiban pajakannya. Kesdaran wajib pajak berpengaruh signifikan dan positif terhadapkepatuhan WP Badan dalam memenuhi kewajiban pajakannya. Kualitas 
pelayanan perpajakan berpengaruh signfikan dan positif terhadap kepatuhan WP Badan dalam memenuhi kewajiban perpajakannya. Pemeriksa, kesadran dan kualitis pelayanan secara bersama-sama berpengaruh pada tingkat kepatuhan wajib pajak.

Berdasarkan pada hasil dari penelitian ini, maka saran yang dapat peneliti ajukan yaitu : Sebaiknya KPP Pratama Semarang Barat agar lebih semangat lagi melakukan sosialiasi terhdap wajib pajak, sehingga dapat menambahkan kesadaran wajib pajak dalam membayar pajak. Ruang lingkup penelitian ini hanya pada WP Badan untuk memakai sistem norma yang terdaftar di KPP. Jadi disarankan untuk penelitian selanjutnya bisa dilaksanakan dengan ruang lingkup yang lebih luas, sehingga dapat menghasilkan penelitian yang lebih baik. Seperti menggunakan wajib pajak orang pribadi yang berpekerjaan bebas sehingga penelitian ini dapat digenerelesasikan untuk penelitian selanjutnya.

\section{DAFTAR PUSTAKA}

Anggraeni, M. D. 2011. Pengaruh Pemanfaatan Fasilitas Perpajakan Sunset Policy Terhadap Tingkat Kepatuhan Wajib Pajak. Skripsi. Semarang: Universitas Diponegoro.

Arum, Harjanti Puspa. 2012. Pengaruh Kesadaran Wajb Pajak, Pelayanan Fiskus, dan Sanksi Pajak terhadap Kepatuhan WPOP yang Melakukan Kegiatan Usaha dan Pekerjaan Bebas. Skripsi. Semarang: Universitas Diponegoro

As'ari, Nur Ghailina dan Teguh Erawati. 2018. Pengaruh pemahaman peraturan perpajakan, kualitas pelayanan, kesadaran wajib pajak dan sanksi pajak terhadap kepatuhan wajib pajak orang pribadi (Studi Empiris pada Wajib Pajak Orang Pribadi Kecamatan Rongkop). Akuntansi Dewantara. 2 (1).

Dewi dan Supadmi. 2014. Pengaruh Pemeriksaan Pajak, Kesadaran, Kualitas, Pelayanan Pada Ingkat Kepatuhan WP Badan Pada KPP Madya Denpasar. E-Jurnal Akuntansi Universitas Udayana. 9 (2).

Eagly, A. H. dan Chaiken, S. 1993. The Psychology of Attitudes. Fort Worth. TX: Harcourt Brace Jovanovitch.

Emalia, Riyatik. 2013. Analisis Pengaruh Pengetahuan, Kesadaran Wajib Pajak serta Pelayanan Petugas Pajak terhadap Kepatuhan Memenuhi Kewajiban Pajak Penghasilan (Studi Empiris pada Pegawai Negeri Yang Ada di Lingkup Universitas). I (1): 91-96.

Ghozali, Imam, 2013. Aplikasi Analisis Multivariate dengan SPSS. Semarang: BPFE Undip.

Gibbon, J. 2006. Employee Engagement A Review of Current Research and Its Implications. USA: The Conference Board

Gunadi. 2013. Panduan Komprehensif Pajak Penghasilan. Jakarta : Bee Media Indonesia.

Gunarso, P. 2016. Pemeriksaan Pajak Dan Sanksi Pajak Terhadap Kepatuhan Pajak Badan Pada

KPP Kepanjen Kabupaten Malang. Jurnal Keuangan dan Perbankan. 20 (2): 214-223

Handayani, Kadek Putri. 2013. Pengaruh Efektifitas E-SPT Masa PPN Pada Kepatuhan WP Badan di KPP Pratama Denpasar Barat. E-Jurnal Akuntansi Universitas Udayana. 4 (1).

Hardiningsih, Pancawati. 2011. Faktor-Faktor Yang Mempengaruhi Kemauan Membayar Pajak. Dinamika Keuangan dan Perbankan. 3 (1): 126 - 142.

Herryanto, Marisa \& Agus Arianto Toly. 2013. Pengaruh Kesadaran Wajib Pajak, Kegiatan Sosialisasi Perpajakan, dan Pemeriksaan Pajak Terhadap Penerimaan Pajak Penghasilan di KPP Pratama Surabaya Sawahan. Tax \& Accounting Review. 1(1): 124.

Hartono, Jogiyanto. 2015. Teori Portofolio dan Analisis Investasi. Edisi Kelima. Jakarta: Rajawali Pers

Jatmiko, A.N. 2006. Pengaruh Sikap Wajib Pajak pada Pelaksanaan Sanksi Denda, Pelayanan Fiskus dan Kesadaran Perpajakan terhadap Kepatuhan Wajib Pajak (Studi Empiris terhadap Wajib Pajak Orang Pribadi di Kota Semarang). Tesis. Semarang: Universitas Diponegoro.

Jogiyanto, 2007. Sistem Informasi Keperilakuan. Yogyakarta: Andi. 
Kompas.com. 2017. Ditjen Pajak: Kepatuhan Bayar Pajak Masyarakat Indonesia MasihRendah. Available at: https://ekonomi.kompas.com/read/2017/07/19/193000326/ditjen-pajak-kepatuhan- . Dunduh pada 16 Juli 2018.

Kosasih. 2008. Analisa Jumlah Wajib Pajak dan Pemeriksaan Pajak Terhadap Realisasi Penerimaan Pajak Pada Kantor Pajak XXX. Jurnal Manajemen. 6(2): 285.

Layata, Setiawan. 2014. Pengaruh Kewajiban Moral, Kualitas Pelayanan, Pemeriksaan Pajak Dan Sanksi Perpajakan Pada Kepatuhan Wajib Pajak Badan. E-Jurnal Akuntansi Universitas Udayana.9 (2): 540-556

Mandagi. 2014. Pengaruh Pemeriksaan Pajakterhadap Tingkat Kepatuhan WP Badan Dalam Memenuhi Kewajiban Perpajakannya Pada KPP Pratama Manado. Jurnal Akuntansi.

Mardiasmo. 2011. Perpajakan. Edisi Revisi. Yogyakarta: Andi. . 2014. Akuntansi Sektor Publik. Yogyakarta: Andi.

Munandar. 2014. Pengaruh Sikap dan Norma Subjektif terhadap Niat Menggunakan Produk Perbankan Syariah Pada Bank Aceh Syariah di Kota Lhokseumawe. Jurnal Visioner \& Strategis.3 (2).

Nur Indriantoro. 2002. Metodelogi Penelitian Bisnis untuk Akuntansi dan Manajemen. Cetakan 2. Yogyakarta: BPFE.

Pemerintah Republik Indonesia. 2009. Undang-Undang Republik Indonesia Nomor16 Tahun 2009 tentang Perubahan Keempat Atas Undang-Undang Nomor 6 Tahun 1983.

Peraturan Menteri Keuangan. 2013. Surat Keputusan Menteri Keuangan Nomor 17/PMK.03/2013 Tentang Tata Cara Pemeriksaan Pajak.

Rahayu, S. K. 2013. Perpajakan Indonesia: Konsep dan Aspek Formal. Edisi kedua. Yogyakarta: Graha Ilmu

Resmi, Siti. 2016. Perpajakan: Teori Dan Kasus. Edisi delapan. Jakarta: Salemba Empat.

Ritonga, Pandapotan. 2012. Pengaruh Penagihan Pajak Dengan Surat Paksa Terhadap Kepatuhan Wajib Pajak Di Kantor Pelayanan Pajak Pratama Medan Timur. Jurnal Ilmiah Sains dan Komputer. 11 (3).

Rizkilina dan Pratomo. 2015. Pengaruh Pengawasan Dan Konsultasi Pajak Dan Pemeriksaan Pajak Terhadap Tingkat Kepatuhan Pajak Penghasilan Badan Tahun 2011-2013 Pada KPP Madya Bandung. E-Proceeding of Management. 2 (2): 1632-1639

Rosdiana dan Irianto. 2011. Panduan Lengkap Tata Cara Perpajakan di Indonesia. Jakarta: Visimedia Pustaka.

Santoso, Singgih. 2012. Analisis SPSS pada Statistik Parametrik. Jakarta: PT. Elex Media Komputindo.

Setia, H. 2015. Pengaruh Frekuensi Pemeriksaan Pajak Dan Kualitas Pemeriksa Pajak Terhadap Tingkat Kepatuhan WP Badan. Jurnal Bisnis dan Akuntansi.17 (1): 10-22

Sugiyono. 2013. Metode Penelitian Pendidikan Pendekatan Kuantitatif, Kualitatif, Dan R\&D. Bandung: Alfabeta.

Trihendradi. 2012. Step by Step SPSS 20 Analisis Data Statistik. Yogyakarta: Andi.

Waluyo. 2011. Perpajakan Indonesia. Jakarta: Salemba Empat. 